\title{
The influence of fertilizaiton with liquid cattle manure on the nutritive value of lucerne forage for ruminants
}

\section{J.J. Pająk, T. Żebrowska, P. Dakowski, Z. Długołęcka and B. Kowalik}

The Kielanowski Institute of Animal Physiology and Nutrition, Polish Academy of Sciences

05-110 Jablonna, Poland

\section{ABSTRACI}

The rumen effective degradability of protein from the first growth of lucene $\mathrm{c} v$. Rival and the intestinal digestibility of protcin udegraded in the rumen, depending on vegetation stage and fertilizaiton with liquid cattle manure, were estimated. Fertilization with manure resulted in increased intestinal digestibility of rumen undegraded protein but also adversely increased protein effective degradability in the rumen. The consquence was an increased PDIN content while the PDIE content was only slightly affected by manure treatment and stage of growth.

KEY WORDS: lucerne, liquid manure, protein value, ruminants

\section{INTRODUCTION}

One of the ways of utilizing liquid cattle manure is spreading it on permanent forage fields, sometimes also on lucerne. In certain periods of the year, on some farms lucerne forage is the main component of the ration for cattle. Its nutritive value changes depending on the soil and climatic conditions, but mainly on the growth stage of the plants. In several studies on cattle and pigs, the effects of fertilizaiton with manure on the yield of lucerne and its chemical composition were studied (Matsumusa and Ota, 1978; Harasimowicz-Hermann, 1991; Kim et al., 1991), however, the extent of protein degradation or ileal digestibility of rumen-undegraded protein were not determined. Application of cattle manure for 3 years to lucerne increased the soil carbon and nitrogen content and improved the 
basic soil fertility index. The mineral content of lucerne residues also increased following fertilization with liquid cattle manure (Harasimowicz-Hermann, 1991). The use of manure on lucerne fields may affect the composition of nitrogen compounds in the plant, increasing the proportion of non-protein nitrogen and low molecular weight, water-soluble proteins, which undergo rapid degradation in the rumen. These factors may affect protein content, rumen protein degradation and ileal digestibility, i.e. PDIN and PDIE values.

The objective of the study was to determine the nutritive value of the first cut of lucerne in various stages of growth obtained from a field on which liquid cattle manure had been spread over the winter.

\section{MATERIAL AND METHODS}

Samples of the first growth of lucerne (Medicago sativa cv. Rival) were harvested in the vegetative stage, in early budding, during budding, or during flowering, from a lucerne field on which from December to February, a total of $60 \mathrm{~m}^{3}$ of liquid cattle manure had been spread in two doses. The forage harvested in the vegetative and flowering stages was compared with samples from a part of the lucerne filed on which manure had not been spread.

Feed analysis was conducted using AOAC procedures (1990). Rumen digestion of forage proteins was determined according to Mchrez and Ørskov (1977) on three rumen- and duodenum- canniulated cows fed a standard ration composed of meadow hay and barley meal supplemented with a mineral mixture. Effective rumen protein degradfation at $\mathrm{k}=0.06$ was calculated according to Ørskov and McDonald (1979). Intestinal digestibility of rumen undegraded protein was determined according to Hveiplund et al. (1992) by the mobile bag method using bags with $42 \mu \mathrm{m}$ pores.

\section{RESULTS AND DISCUSSION}

The application of manure increased the total protein content in lucerne in the vegetative stage by $12 \%$, and by $18 \%$ during blooming, in comparison with lucerne that was not fertilized by manure (Tabele 1). The crude protein content of manure-fertilized lucerne exceeded INRA values by about $11 \%$ during the budding phase, and by about $26 \%$ during the blooming phase, which confirms that results of Harasimowicz-Hermann (1991). The crude fibre content in the initial period of vegetation and during blooming of luceme did not differ from the values given in the tables, but in the final phases of the first growth of manure-fertilized lucerne it was from 13 to $18 \%$ lower than in the INRA tables. 
TABLE 1

Influence of cattle manure application on $\mathrm{l}^{\text {st }}$ growth lucerne forage dry matter composition, $\mathrm{g}$

\begin{tabular}{lcccccc}
\hline Growth stage & Application & $\begin{array}{c}\text { Crude } \\
\text { protein }\end{array}$ & $\begin{array}{c}\text { Cride } \\
\text { fibre }\end{array}$ & NDF & ADF & ADL \\
\hline Vegetative & without & 225 & 225 & 351 & 299 & 61 \\
Vegetative & liquid manure & 252 & 237 & 414 & 320 & 68 \\
Early bud & liquid manure & 237 & 273 & 451 & 337 & 67 \\
Full bud & liquid manure & 215 & 259 & 433 & 336 & 67 \\
Flowering & liquid manure & 212 & 274 & 459 & 366 & 70 \\
Flowering & without & 179 & 346 & 520 & 404 & 80 \\
\hline
\end{tabular}

The application of manure increased the intestinal digestibility of protein undegraded in the rumen by about $6 \%$ and had an unfavourable influence on the effective rumen protein degradability, increasing it by about $10 \%$ in the vegetative and blooming stages in comparison with control lucerne (Table 2). The INRA tables give one value of effective protein degradation in the rumen (deg) and ileal digesti-

TABLE 2

Influence of cattle manure application on effective protein degradation in the rumen (deg) and the ileal digestibility of rumen undegraded protein (dsi)

\begin{tabular}{lccc}
\hline Growth stage & Application & deg & dsi \\
\hline Vegetative & without & 0.78 & 0.71 \\
Vegetative & liquid manure & 0.85 & 0.75 \\
Early bud & liquid manure & 0.80 & 0.74 \\
Full bud & liquid manure & 0.76 & 0.73 \\
Flowering & liquid manure & 0.75 & 0.74 \\
Flowering & without & 0.68 & 0.70 \\
\hline INRA Feed Tables, fresh foragees - legume & 0.73 & 0.75 \\
\hline
\end{tabular}

bility of rumen undegraded protein (dsi) for all fresh legume forages. In manurefertilized lucerne, dsi did not differ from the values given in the tables, but the lucerne that was not fertilized with manure, the value of dsi was a bit lower. The deg value for lucerne fertilized with manure as well as in the initial stage of growth of lucerne not fertilized with manure were higher than the values given in the INRA tables, which affects the values of PDIN and PDIE. Similar values of effective protein degradation of lucerne from the first cutting are given by Antoniewicz et al. (1995). 
When using manure, the PDIN of lucerne cut in the vegetative stage and during blooming was 13 and $18 \%$ higher, respectively, than in lucerne not fertilized with manure (Table 3). Use of manure increased PDIE by about 7\%, regardless of the growth phase of the plants. The PDIN content in samples of lucerne decreased by $17 \%$ in the unfertilized and $13 \%$ in the manure-treated lucerne as growth proceded from the vegetative to the blooming stage. The rise in the PDIE content in lucerne as vegetation progressed was similar regardless of whether manure was used or not, and equaled about $5 \%$.

TABLE 3

Influence of cattle manure application on $1^{\text {st }}$ growth lucerne forage protein value for ruminants, g/kg DM

\begin{tabular}{lccc}
\hline Growth stage & Application & PDIN & PDIE \\
\hline Vegetative & without & 135 & 79 \\
Vegetative & liquid manure & 152 & 85 \\
Early bud & liquid manure & 145 & 89 \\
Full bud & liquid manure & 132 & 84 \\
Flowering & liquid manure & 132 & 89 \\
Flowering & without & 112 & 83 \\
\hline
\end{tabular}

The PDIN of manure-fertilized lucerne exceeded the INRA table values by $8 \%$ in the vegetative stage to $25 \%$ in the blooming phase. Lucerne not fertilized with manure had $4 \%$ less PDIN in the vegetative stage and $6 \%$ more in the blooming phase than in the INRA tables. The PDIE content in the vegetative stage of both types of forage was from 16 to $22 \%$ lower than in the INRA tables, while lucerne in bloom contained from 10 and $3 \%$ more PDIE, respectively, than INRA figures, when manure was or was not used. In the studies of Antoniewicz et al. (1995) only lucerne in the vegetative stage of growth contained $87 \mathrm{~g}$ PDIN in dry matter, while in the remaining stages the PDIN content was even lower than in our study and did not exceed $80 \mathrm{~g}$ (57 $\mathrm{g}$ in full bloom to $77 \mathrm{~g}$ in early budding).

In the studied samples of manure-fertilized lucerne, we did not observe an increased proportion of weeds in comparison with the lucerne that was not fertilized with manure, which is in agreement with the results of Kim et al. (1991), who found that the botanical composition with early application of $30 \mathrm{~m}^{3}$ slurry + fertilizer was relatively constant during the 4 years.

\section{CONCLUSIONS}

Spreading liquid cattle manure increases the intestinal digestibility of rumenundegraded protein and unfavourably increases effective protein degradability in 
the rumen. Spreading of liquid manure mainly increases the PDIN content, whereas the PDIE content changes to a lesser degree than PDIN, regardless of whether manure is applied or not and regardless of the growth stage.

\section{REFERENCES}

Antoniewicz A.M., Kowalczyk J., Kanski J., Gorska-Matusiak Z., Nalepka M., 1995. Rumen degradability of crude protein of dried grass and lucerne forage measured by in sacco incubation and predicted by near infrared spectroscopy. Anim. Feed Sci. Tech. 54, 203-216

Harasimowicz-Hermann G., 1991. Changes in chemical composition of soil as an effect of several years' fertilization of alfalfa (Medicago media L.) with slurry and liquid manure. Chem. Agr. Environ., Royal Soc. Chem., pp. 209-220

Hvelplund T., Weisbjerg M.R., Andersen L.S., 1992. Estimation of the true digestibility of rumen undegraded dietary protein in the small intestine of ruminants by the mobile bag technique. Acta Agr. Scand., Sect. A. Anim. Sci. 42, 34-39

INRA,1993. Ruminant Nutrition. Recommended Allowances and Feed Tables. E. Jarrige (Editor). Polish Edition, The Kielanowski Institute of Animal Physiology and Nutrition. Jabłonna (Poland) pp. 406

Kim J.K., Park G.J., Lee H.H., Chung E.S., 1991. Studies on the application of cattle slurry in grassland. I. Effects of the application times and levels of cattle slurry on the dry matter yield and botanical composition in grassland. J. Korean Soc. Grass. Sci. 11, 182-188

Matsumusa Y., Ota T., 1978. The effect of dairy cattle slurry application on yields of important forages. Anim. Husb. 32, 1359-1361

Mehrez A.Z., Ørskov E.R., 1977. A study of the artificial fibre bag technique for determining the digestibility of feeds in the rumen. J. Agr. Sci. 88, 645-650

Ørskov E.R., McDonald I., 1979. The estimation of protein degradability in the rumen from incubation measurements weighted according to rate of pasage. J. Agr. Sci. 92, 499-503

\section{STRESZCZENIE}

\section{Wplyw zastosowania gnojowicy bydlęcej na wartość pokarmową lucerny dla przeżuwaczy}

Badano efektywny rozkład białka pierwszego odrostu lucerny Rival w żwaczu oraz strawność jelitową białka nie rozłożonego w żwaczu w zależności od stadium wegetacji i nawożenia w porównaniu z zielonką nie nawożoną gnojowicą Stwierdzono, że nawożenie gnojowicą spowodowało wzrost strawności jelitowej białka nie rozłożonego w żwaczu oraz niekorzystnie zwiększyło wielkość efektywnego rozkładu białka w żwaczu. Konsekwencją tego było zwiększenie zawartości BTJN, natomiast zawartość BTJE zmieniała się nieznacznie tak przy zmianie nawożenia, jak i fazy zrostu. 